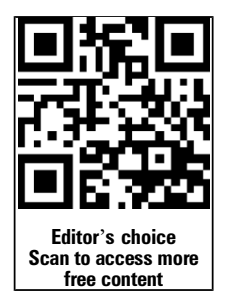

Additional material is published online only. To view please visit the journal online (http://dx.doi.org/10.1136/ jmedgenet-2015-103218).

For numbered affiliations see end of article.

\section{Correspondence to} Dr Mercedes Robledo, Hereditary Endocrine Cancer Group, Human Cancer Genetics Programme, Centro Nacional de Investigaciones Oncológicas, Melchor Fernández Almagro 3, Madrid 28029, Spain:

mrobledo@cnio.es

Received 22 April 2015 Revised 14 July 2015 Accepted 18 July 2015 Published Online First 12 August 2015

\section{(1) CrossMark}

To cite: Currás-Freixes $M$, Inglada-Pérez L, Mancikova V, et al. J Med Genet 2015:52:647-656.

\title{
Recommendations for somatic and germline genetic testing of single pheochromocytoma and paraganglioma based on findings from a series of 329 patients
}

Maria Currás-Freixes, ${ }^{1}$ Lucía Inglada-Pérez, ${ }^{1,2}$ Veronika Mancikova, ${ }^{1}$ Cristina Montero-Conde, ${ }^{1}$ Rocío Letón, ${ }^{1}$ Iñaki Comino-Méndez, ${ }^{1}$ María Apellániz-Ruiz, ${ }^{1}$ Lara Sánchez-Barroso, ${ }^{1}$ Miguel Aguirre Sánchez-Covisa, ${ }^{3}$ Victoria Alcázar, ${ }^{4}$ Javier Aller, ${ }^{5}$ Cristina Álvarez-Escolá, ${ }^{6}$ Víctor M Andía-Melero, ${ }^{7}$ Sharona Azriel-Mira, ${ }^{8}$ María Calatayud-Gutiérrez, ${ }^{9}$ José Ángel Díaz, ${ }^{10}$ Alberto Díez-Hernández, ${ }^{11}$ Cristina Lamas-Oliveira, ${ }^{12}$ Mónica Marazuela, ${ }^{13}$ Xavier Matias-Guiu, ${ }^{14}$ Amparo Meoro-Avilés, ${ }^{15}$ Ana Patiño-García, ${ }^{16}$ Susana Pedrinaci, ${ }^{17}$ Garcilaso Riesco-Eizaguirre, ${ }^{18}$ Constantino Sábado-Álvarez, ${ }^{19}$ Raquel Sáez-Villaverde, ${ }^{20}$ Amaya Sainz de los Terreros, ${ }^{21}$ Óscar Sanz Guadarrama, ${ }^{22}$ Julia Sastre-Marcos, ${ }^{23}$ Bartolomé Scolá-Yurrita, ${ }^{24}$ Ángel Segura-Huerta, ${ }^{25}$ Maria de la Soledad Serrano-Corredor, ${ }^{26}$ María Rosa Villar-Vicente, ${ }^{27}$ Cristina Rodríguez-Antona, ${ }^{1,2}$ Esther Korpershoek, ${ }^{28}$ Alberto Cascón, ${ }^{1,2}$ Mercedes Robledo ${ }^{1,2}$

\section{ABSTRACT}

Background Nowadays, $65-80 \%$ of

pheochromocytoma and paraganglioma (PPGL) cases are explained by germline or somatic mutations in one of 22 genes. Several genetic testing algorithms have been proposed, but they usually exclude sporadic-PPGLS (S-PPGLS) and none include somatic testing. We aimed to genetically characterise S-PPGL cases and propose an evidence-based algorithm for genetic testing, prioritising DNA source.

Methods The study included 329 probands fitting three criteria: single PPGL, no syndromic and no PPGL family history. Germline DNA was tested for point mutations in RET and for both point mutation and gross deletions in VHL, the SDH genes, TMEM127, MAX and FH. 99 tumours from patients negative for germline screening were available and tested for RET, VHL, HRAS, EPAS1, MAX and SDHB.

Results Germline mutations were found in 46 (14.0\%) patients, being more prevalent in paragangliomas (PGLs) $(28.7 \%)$ than in pheochromocytomas (PCCs) $(4.5 \%)$ $\left(p=6.62 \times 10^{-10}\right)$. Somatic mutations were found in $43 \%$ of those tested, being more prevalent in PCCs (48.5\%) than in PGLs $(32.3 \%)(p=0.13)$. A quarter of $S-P P G L s$ had a somatic mutation, regardless of age at presentation. Head and neck PGLs (HN-PGLs) and thoracic-PGLs (T-PGLs) more commonly had germline mutations ( $p=2.0 \times 10^{-4}$ and $p=0.027$, respectively). Five of the 29 metastatic cases harboured a somatic mutation, one in HRAS.

Conclusions We recommend prioritising testing for germline mutations in patients with HN-PGLS and TPGLs, and for somatic mutations in those with PCC. Biochemical secretion and SDHB-immunohistochemistry should guide genetic screening in abdominal-PGLs. Paediatric and metastatic cases should not be excluded from somatic screening.

\section{INTRODUCTION}

Pheochromocytomas (PCCs) and paragangliomas (PGLs), together abbreviated to PPGLs, are neuroendocrine tumours originating from neural crestderived chromaffin cells and arising in the adrenal medulla and extra-adrenal paraganglia, respectively. PCCs and PGLs localised in the thorax (T-PGLs) and abdomen (A-PGLs) are derived from sympathetic lineage and tend to be functional by secreting catecholamines. Head and neck PGLs (HN-PGLs) are derived from parasympathetic lineage and are usually non-secreting.

Although rare, with a reported prevalence of $0.2-0.6 \%$ in patients with arterial hypertension, ${ }^{1}$ PPGLs show the highest degree of heritability of all human neoplasias. ${ }^{2} 3$ Since the description of the NF1 gene in $1990,{ }^{4}$ numerous discoveries related to the genetic background of PPGLs have been made, and it is now known that around $70 \%$ of PPGLs are associated with a mutation in one of the 22 known PPGL-related genes, either germline only (in SDHC, KIF1 $\beta$, SDHAF2, TMEM127, $S D H A$ or $F H$ ), ${ }^{2}$ somatic only (in HRAS), ${ }^{2}$ germline or somatic (in NF1, RET, VHL, SDHD, ${ }^{5} S D H B^{6}$ or $M A X)^{2}$ or somatic and somatic mosaicism (in EPAS1). ${ }^{2}$ Mutations in other genes, such as MEN1, ${ }^{7}$ EGLN1, EGLN2, ${ }^{8} \mathrm{MDH}_{2}{ }^{9}$ and IDH1, have been reported in single cases or families suggesting that their contribution to the disease is 
modest. In addition, somatic mutations in $A T R X,{ }^{10} B R A F$ and TP5 $3^{11}$ have been described, but their role is yet to be established.

Systematic genetic screening of all PPGL-related genes is an expensive and time-consuming task and so algorithms are required to guide genetic testing based on the presence of associated pathologies or clinical or molecular features. Information on indicators of hereditary disease (such as positive family history, syndromic features or metastatic, extra-adrenal, multifocal or bilateral presentation), age at diagnosis, tumour location, biochemical phenotype and particularly SDHB/ SDHA-immunostaining, makes it possible to prioritise genes for

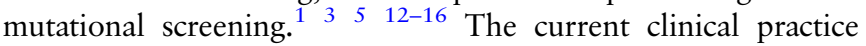
guidelines for PPGLs ${ }^{1}$ recommend that for cases with indicators of low heritability (unilateral PCC without syndromic features or metastatic presentation, or PPGLs without a family history of the disease), the decision to perform germline genetic testing be balanced between the cost of testing and the psychological impact on the patient and their family of not having a test that might explain why they have the disease. These cases have been referred to as sporadic-PPGLs (S-PPGLs).

It has been reported that 11-24\% of S-PPGLs harbour a germline mutation in a PPGL-related gene, ${ }^{14} 15{ }^{17-20}$ and therefore algorithms focused specifically on S-PPGLs have been also proposed. ${ }^{14} 15$ 17-20 However, none of them contemplate testing for somatic mutations, which seem to also be relevant in S-PPGLs. ${ }^{1}$ Somatic mutations can cause metastatic ${ }^{21-23}$ and paediatric ${ }^{21}$ cases, as well as PPGLs diagnosed before the age of 40 years. $^{21} 24-26$ Despite this knowledge, in routine clinical practice S-PPGLs have been excluded from comprehensive genetic screening beyond $S D H B$ mutations, and even that is not always performed. Gene panels using next-generation sequencing (NGS) are a promising genetic diagnostic tool because they are faster and cheaper than the classically used Sanger sequencing. $^{11} 23$ 27-30 However, assessing the large amount of sequence data and variants of unknown significance generated, and applying appropriate biological interpretation of these results, remains a challenge. Thus, their use is yet to be optimised in daily clinical practice for all PPGL cases. Additionally, as a diagnostic tool, gene panel testing needs to be complemented with the study of gross deletions with multiplex ligationdependent probe amplification (MLPA) or multiplex PCR, and with Sanger sequencing of the exonic regions that cannot be correctly sequenced by NGS. ${ }^{3}$

Therefore, information about germline and somatic mutations in S-PPGLs is still scarce, and there is no recommendation about whether germline or tumour DNA should be prioritised for testing. Therefore, while currently available algorithms may be useful, they require updating.

This study aimed to assess the prevalence of somatic and germline mutations in S-PPGLs, and to propose an algorithm that includes a recommendation about the type of material to be used in distinct scenarios.

\section{METHODS}

\section{Patients and tumours}

The inclusion criteria for patients with S-PPGL included: (1) the presence of a single PPGL (focal and unilateral); (2) the absence of syndromic features of neurofibromatosis type 1, multiple endocrine neoplasia type 1 and type 2 and von Hippel-Lindau syndrome in the patient and their relatives and (3) the absence of a family history of PPGL. The diagnosis was based on pathological study and plasma or urinary catecholamines/metanephrines; plus imaging tests for parasympathetic PGLs.
A blood sample was collected from eligible patients and a complete clinical questionnaire was completed at Spanish public hospitals (see online supplementary materials and methods).

A total of 329 unrelated Spanish index cases with S-PPGLs were recruited between 1997 and 2014: 60.8\% were PCCs and 39.2\% were PGLs. Among PGLs, $47.3 \%$ were HN-PGLs, $10.1 \%$ were T-PGLs, $41.9 \%$ were A-PGLs and the location of one PGL was not specified. The median age at onset was 46 (IQR: 35-59) years and 58\% were women.

Physicians were recontacted to request a frozen or formalinfixed paraffin-embedded (FFPE) tumour sample from patients with negative germline genetic screening. Of 99 tumour samples collected, 75 were FFPE and were evaluated for SDHB-immunohistochemistry (SDHB-IHC) using anti-SDHB rabbit polyclonal antibodies (Sigma-Aldrich Corp). SDHA-IHC was performed on tumours testing negative on SDHB-IHC, as previously described. ${ }^{31}$ Staining was considered positive when mitochondrial-specific granular labelling was identified, which suggests the absence of a mutation in the SDH genes. ${ }^{32}$ Frozen tumours were not tested for SDHB/SDHA-IHC because this technique was not optimised for this type of sample. All patients provided informed consent.

\section{DNA extraction and mutation testing}

DNA was extracted from blood following a standard method ${ }^{33}$ and from frozen/FFPE tissue using the DNeasy kit (Qiagen Inc.), following the manufacturer's instructions.

Germline DNA from each patient was tested by Sanger sequencing for mutations in RET (ENST00000355710, exons 10, 11, 13-16), VHL (ENST00000256474, all exons, plus the promoter region), SDHA (ENST00000264932), SDHB (ENST00000375499), SDHC (ENST00000367975), SDHD (ENST00000375549), SDHAF2 (ENST00000301761), TMEM127 (ENST00000258439), MAX (ENST00000358664) and $F H$ (ENST00000366560). Testing for gross deletions in VHL, SDHB, SDHC, SDHD, SDHAF2, TMEM127, MAX and $F H$ was done by MLPA (MRC-Holland) or multiplex PCR, as previously described. ${ }^{34-36}$

The study of somatic mutations was carried out based on biochemical secretion and SDHB-IHC, the latter only if an FFPE sample was available. Hence, RET was studied in adrenergic secreting tumours, VHL in noradrenergic secreting tumours and $S D H B$ if SDHB-IHC showed negative staining or could not be determined. SDHC and SDHD were only tested if SDHB-IHC was negative and SDHA-IHC was positive. EPAS1 (ENST00000263734), H-RAS (ENST00000451590), MAX, RET and VHL were studied for somatic mutations in tumours from cases for which no SDHB-IHC or biochemical secretion data were available, or when secretion was not detected, in the latter scenario because it was not known whether this was due to the tumour being non-secreting or exhibiting paroxysmal secretion. Because the predominant secretion pattern has not been clearly established for EPAS1 and HRAS, and because MAX-mutated cases present both types of secretion, all tumours (except one with negative SDHB-IHC) were studied for somatic mutations in these three genes. Thus, the somatic study included HRAS (exons 2-3), EPAS1 (exon 12) and MAX in 98 tumours, VHL (promoter region as well as exons $1-3$ ) in 80 tumours, RET (exons 10, 11 and 16) in 59 tumours, $S D H B$ (all exons) in 23 tumours and SDHC and SDHD (all exons) only in 1 tumour. Finally, we studied somatic mutations in NF1 (ENST00000358273, all exons, using primers described ${ }^{37}$ ) in adrenergic PPGL in which frozen tumour sample was available (five tumours). NF1 was analysed in one of the tumours by NGS as part of another study 
(data not shown); the mutation was confirmed by Sanger sequencing in tumour DNA and ruled out in germline DNA.

The details summarising the steps of the study are shown in online supplementary figure S1. The assessment of the pathogenicity of the variants found is described in online supplementary materials and methods.

\section{Statistical analysis}

We used Pearson's $\chi^{2}$ test, or Fisher's exact test when necessary, to compare proportions. Two-sided $\mathrm{p}$ values $<0.05$ were considered statistically significant. Statistical analyses were performed using IBM SPSS statistics V.17.0 (IBM, Armonk, New York, USA) and R software V.2.7.2 (http://www.r-project.org/) was used to generate figure 1 .

\section{RESULTS}

\section{Clinical characterisation}

The clinical characteristics of cases are detailed in table 1 . Clinical and genetic data from the 329 patients included in the study are shown in online supplementary table S1. The clinical presentation of S-PPGLs was mainly symptomatic (71.4\%). Adrenergic symptoms were the predominant clinical presentation in PCCs (68.1\%), T-PGLs (37.5\%) and A-PGLs (47.7\%), while local mass symptoms were more common in HN-PGLs (79.4\%). PCCs and A-PGLs were predominantly secreting tumours (96.1\% and 94.6\%, respectively), HN-PGLs were more often non-secreting tumours $(80 \%)$ and T-PGLs were a more even mix of both. Although the proportion of the secreting HN-PGL seems to be higher than previously described, ${ }^{38}$ it is important to note that we did not have this information for all patients. In these patients with secreting HN-PGL, additional PPGLs were ruled out using images techniques. Fifteen paediatric cases (diagnosed at or under the age of 18 years) were recruited, all derived from sympathetic lineage: seven PCCs, one T-PGL and seven A-PGLs, and most (83.3\%) presenting with adrenergic symptoms. Twenty-nine cases had developed metastases, which were more common in PGLs (14.0\%) than in PCCs $(5.5 \% ; \mathrm{p}=0.008)$, and in T-PGLs $(38.5 \%)$ than in HN-PGLs (8.2\%) or A-PGLs (13.0\%) $(\mathrm{p}=0.012$ and $\mathrm{p}=0.046$, respectively).

\section{Genetic characterisation}

Genetic analysis revealed mutations in 89 (27.1\%) of 329 S-PPGLs; 46 were germline (14\%) and 43 were somatic $(43.4 \%$ of the 99 tumours tested). A summary of the assessment of each variant found (mutation vs variant of unknown significance) is shown in online supplementary table S2. Germline mutations were more prevalent in PGLs $(37 / 129,28.7 \%)$ than in PCCs $(9 / 200,4.5 \%)\left(p=6.62 \times 10^{-10}\right)$. The most frequently germlinemutated gene in S-PPGLs was SDHB (29/46, 63.0\%). This result was expected due to the existence of founder effects affecting this gene in the Spanish population. ${ }^{20}$ The number of mutations in other genes was six for SDHD, two for SDHC, two for RET and one for VHL mutation. Moreover, as previ-

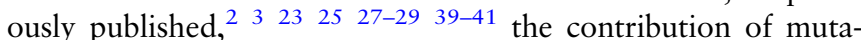
tions in 'new' PPGL-genes was minor: three in SDHA (0.9\%), one in SDHAF2 (0.3\%), two in TMEM127 (0.6\%) and no FH and $M A X$ mutations.
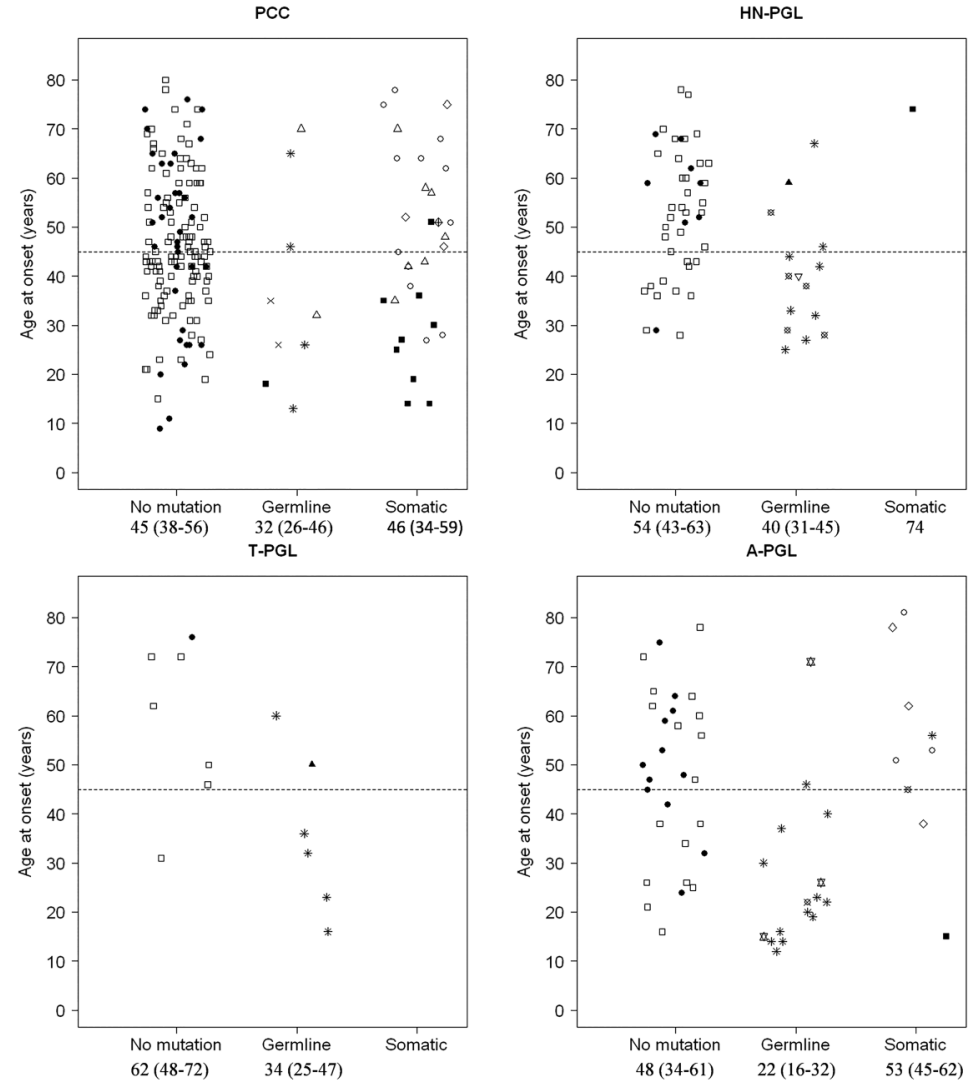

口 WT with only germline DNA available

- WT with germline and tumor DNA available

HRAS

$\diamond$ EPASI

$\triangle R E T$

- $V H L$

* $S D H B$

×DHD

$\triangle S D H C$

$\nabla S D H A F 2$

SS SDHA

$\times$ TMEM127

$\oplus N F I$

Figure 1 Age at disease onset by tumour location and genetic mutation status (germline mutation, somatic mutation, no mutation found in germline DNA study or no mutation found in germline plus tumour DNA study). The median and IQR of age in years at disease onset are shown for each group. A-PGL, abdominal-paraganglioma; HN-PGL, head and neck-paraganglioma; PCC, pheochromocytoma; T-PGL, thoracic-paraganglioma; WT, wild type. 


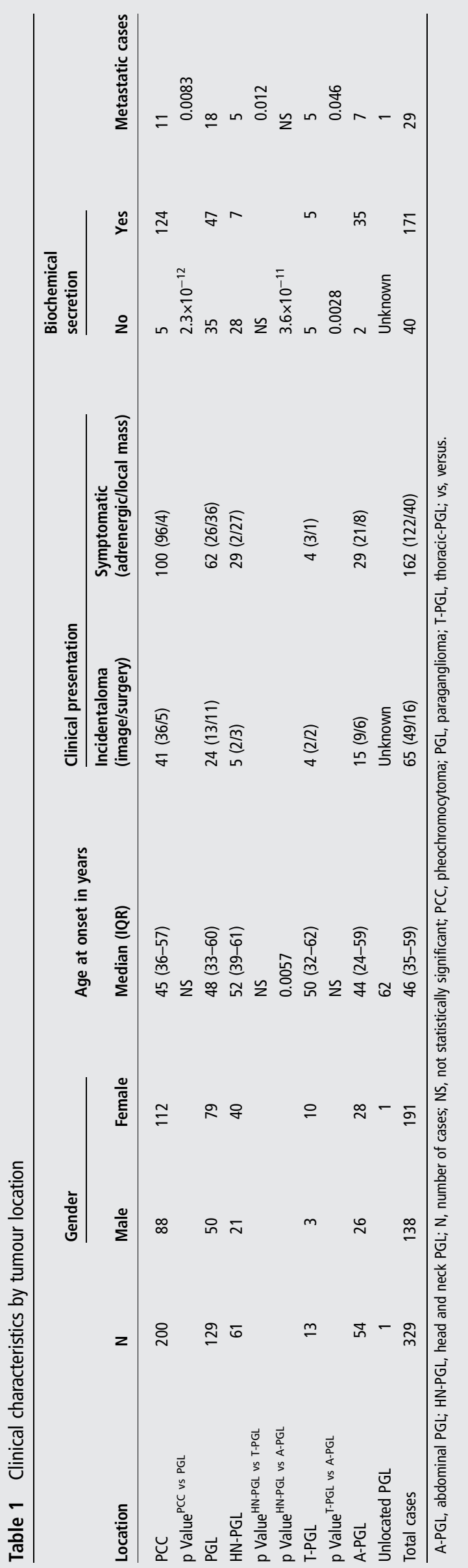

Among the 99 tumour samples, 68 were PCCs and 31 PGLs. Among the 75 FFPE samples, all except one showed positive SDHB-IHC. Somatic mutations were more prevalent in PCCs $(48.5 \%)$ than in PGLs $(32.3 \% ; \mathrm{p}=0.13)$. HRAS was the gene most often somatically mutated $(15.3 \%$ of the 98 tumours tested), followed by VHL (11/80, 13.8\%), RET (8/59, 13.6\%), EPAS1 (6/98, 6.1\%), SDHB (1/23, 4.3\%) and NF1 and SDHD (one case each). A summary of the genetic testing is presented in online supplementary figure S2.

\section{Tumour location}

To make a recommendation about which type of sample should be prioritised for genetic screening of the known PPGL-related genes, and to avoid an overestimation of the frequency of patients with somatic mutations, not only the 99 germlinenegative cases with tumour material available were included in the analysis, but also the 46 germline-positive patients. The remaining 184 germline-negative cases were excluded from this study since tumour material was not available and thus, somatic screening was not feasible. Statistically significant differences were found between PCCs and PGLs regarding the proportion of somatic mutation carriers versus germline mutation carriers $\left(p=6.67 \times 10^{-8}\right)$. In this subset of patients, somatic mutations were found in $4.2 \%$ of HN-PGLs, $0 \%$ of T-PGLs, $24.3 \%$ of A-PGLs and $42.9 \%$ of PCCs. Among all locations, HN-PGLs and T-PGLs were mainly associated with germline mutations $\left(\mathrm{p}=2.0 \times 10^{-4}\right.$ and $\mathrm{p}=0.027$, respectively) (table 2$)$.

The most frequently mutated gene in PCCs was HRAS, while $S D H B$ was the major contributor in PGLs regardless of their location, followed by SDHD in HN-PGLs, even though the involvement of this gene has been mainly related to multiple PPGLs. ${ }^{2}$ In A-PGLs, SDHA, EPAS1 and HRAS were mutated with similar frequency (three cases each). Genetic results by tumour location, and clinical characteristics by gene mutated, are detailed in table 3 .

\section{Utility of predominant secretion of PPGLs to guide genetic screening}

HRAS-mutated, RET-mutated and NF1-mutated S-PPGLs presented predominantly adrenergic secretion. EPAS1-mutated, VHL-mutated, SDHB-mutated and SDHA-mutated S-PPGLs had, as expected, noradrenergic secretion. Only two TMEM127-mutated cases were found, one with adrenergic and the other with noradrenergic secretion. The case in our series with a mutation in SDHAF2 showed mainly adrenergic secretion. The result from an assessment of genes mutated by location, for adrenergic and noradrenergic secreting tumours, suggested that in case of noradrenergic secreting tumours, $V H L$ should be tested before $\operatorname{SDHB}\left(\mathrm{p}=3.51 \times 10^{-5}\right)$ and $\operatorname{SDHD}\left(\mathrm{p}=7.1 \times 10^{-4}\right)$ in PCCs, SDHD before VHL $(\mathrm{p}=0.0095)$ in HN-PGLs and SDHB before VHL $(\mathrm{p}=0.0024)$ in thoracic plus abdominal-PGLs (TA-PGLs) (see online supplementary table S3). However, no statistically significant differences were found in adrenergic tumours between the proportions of HRAS-mutated and RET-mutated cases for each location (table 3).

\section{Paediatric presentation}

Data on age at presentation by tumour location and genetic mutational status are summarised in figure 1 . The median age at onset for germline mutation carriers was lower than that for somatic mutation carriers and cases without a mutation.

Driver mutations were more frequently found in paediatric than in adult cases $(73.3 \%$ vs $25.2 \%, \mathrm{p}=0.00020)$. Germline mutations were found in $53.3 \%$ of children, involving $S D H B$ in 
Table 2 Summary of genotype profile by tumour location for cases with germline and tumour DNA available

\begin{tabular}{llllllll}
\hline Location & $\begin{array}{l}\text { Total } \\
\mathbf{N}=\mathbf{1 4 5}\end{array}$ & $\begin{array}{l}\text { Germline mutation } \\
\mathbf{N}=\mathbf{4 6}\end{array}$ & $\begin{array}{l}\mathrm{p} \text { Value } \\
\text { Germline vs somatic mutation }\end{array}$ & $\begin{array}{l}\text { Somatic mutation } \\
\mathbf{N}=\mathbf{4 3}\end{array}$ & $\begin{array}{l}\text { Total mutated } \\
\mathbf{N}=\mathbf{8 9}\end{array}$ & $\begin{array}{l}\mathrm{p} \text { Value } \\
\text { Mutated vs non-mutated }\end{array}$ & $\begin{array}{l}\text { Non-mutated } \\
\mathbf{N}=\mathbf{5 6}\end{array}$ \\
\hline PCC & 77 & 9 & & 33 & 42 & & 35 \\
PGL & 68 & 37 & $6.67 \times 10^{-8}$ & 10 & 47 & NS & 21 \\
HN-PGL & 24 & 15 & $2.0 \times 10^{-4}$ & 1 & 16 & NS & 8 \\
T-PGL & 7 & 6 & 0.027 & 0 & 6 & NS & 1 \\
A-PGL & 37 & 16 & NS & 9 & 25 & NS & 12 \\
TA-PGL & 44 & 22 & 0.0078 & 9 & 31 & NS & 13 \\
\hline
\end{tabular}

A-PGL, abdominal PGL; HN-PGL, head and neck PGL; NS, not statistically significant; PCC, pheochromocytoma; PGL, paraganglioma; T-PGL, thoracic-PGL; TA-PGL, thoracic plus abdominal-PGL; vs, versus.

six cases (75\%) and SDHA and VHL in one case each. In addition, three somatic mutations were found in the five tumours available from the paediatric cases with negative germline screening (60\%), all of them in VHL. Proportionally less adult cases $(12.5 \%)$ presented germline mutations $(p=0.00030)$, while somatic mutations were found in a similar percentage $(41.9 \%)$ to that for paediatric patients $(p=0.65)$.

Of paediatric S-PPGL with a bona fide diagnosis (patients with germline mutation and those with negative germline screening and tumour available), 4 (23.1\%) presented a somatic mutation, similar to the $37(29.8 \%)$ somatic mutations found in S-PPGL cases older than 18 years old with a bona fide diagnosis $(p=0.15)$. If only paediatric and adult cases with a bona fide diagnosis were taken into account, no statistically significant differences in the proportion of mutated cases were observed $(p=0.068)$.

\section{Minor but not less important metastatic-related players beyond SDHB gene}

Of the 29 metastatic cases, 19 (65.5\%) carried a driver mutation. Germline mutations were found in 14 (48.3\%), most commonly in SDHB (71.4\%), followed by SDHD (14.3\%). No mutations were found in other genes associated with a higher rate of metastases, such as $\mathrm{MAX}$ and $\mathrm{FH} .{ }^{35} 41$

However, in one metastatic S-PPGL we found a somatic mutation in HRAS, a gene that has not previously been reported to be involved in metastatic PCCs. In addition, as previously described, there were metastatic cases with germline mutations in SDHA, SDHC or with somatic mutations in EPAS1, RET, VHL and SDHD. ${ }^{42}$

\section{DISCUSSION}

\section{Mutation analysis}

Since 2002, several reports have been published on genetic screening in S-PPGLs, with the estimated prevalence of hereditary cases ranging from $11.3 \%$ to $24 \% .^{14} 15$ 17-20 ${ }^{43}$ However, it is difficult to compare these findings because the criteria used to define S-PPGLs varied between studies; some included cases with multifocal ${ }^{19}$ or bilateral $^{1819}$ tumours, or cases with family history, ${ }^{19}$ while others focused on benign tumours ${ }^{17}$ or secreting tumours $^{18} 19$ or included cases diagnosed within a specific age range. ${ }^{43}$ Further, only germline mutations in the PPGL-related genes known at the time (RET, VHL, SDHB, SDHD and SDHC) were considered. That said, in our 2009 study, we found germline mutations in 135 (14\%) of the cases studied, and this report shows the same percentage of hereditary cases, despite having increased the sample size (from 135 to 329) and five additional genes having been included in the analysis. ${ }^{15}$ This is likely explained by the limited contribution of the 'novel'
PPGL-genes: SDHA $\left(<1 \%{ }^{2}\right)$, SDHAF2 $\left(<1 \%{ }^{40}\right)$, TMEM127 $\left(0.9 \%{ }^{39}\right), \operatorname{MAX}\left(1.1 \%{ }^{25}\right)$ and $F H\left(0.83 \%{ }^{41}\right) .^{27-29}$

In recent years, somatic mutations in S-PPGLs have also been reported, highlighting the importance of working with tumour samples to provide a genetic diagnosis. ${ }^{11} \quad 21-26293044$ Our study shows a higher frequency of somatic mutations than the reported $36 \%,{ }^{22}$ probably because we included the study of HRAS and EPAS1, which seems to be relevant to S-PPGL. This higher frequency of mutations was seen for RET, VHL and HRAS; the previously reported prevalences were 5-5.1\%, 8.5$9.2 \%$ and $6.9-10 \%$, respectively. ${ }^{11} 2122 \quad 2426$ On the other hand, our study found a similar frequency of EPAS1 mutations $(6.1 \%)$ to that previously reported $7.9 \%$. $^{44}$

In 2012, two independent studies found somatic NF1 mutations in $24 \%$ and $41 \%$ of PPGL patients, predominantly in PCCs and one A-PGL. ${ }^{22} 23$ For three of the cases, the mutation was found to be in the germline, all had mild features and none had previously been identified as syndromic NF1 patients. ${ }^{22} \mathrm{We}$ found one somatic mutation in NF1 among the five adrenergic frozen tumours available (20\%). This lower percentage is probably due to the limited number of tumours analysed for somatic NF1 mutations. The use of NGS could resolve the difficulties of studying NF1 by Sanger sequencing (large size, the absence of identified hot spots, high cost and time of delivery), and its future use will probably explain a large number of cases with unknown driver mutations.

Only one case had a somatic mutation in SDHB and SDHD. Finally, $M A X$ was not somatically involved in our series, which is consistent with previous reports (1.65-2.5\% frequency). ${ }^{22} 25$ Similar to the COMETE cohort study, where somatic genetic assessment was guided by findings from genome-wide expression studies, ${ }^{21} 22$ our somatic study was, in part, guided by the fractionated biochemical secretion observed for each tumour, highlighting the importance of having access to secretion data. In this regard, it has been already demonstrated that mutation screening of $S D H B$ is unnecessary in metastatic tumours secreting epinephrine. ${ }^{45}$

Although germline mutations in the HRAS and EPAS1 genes have been reported to be associated with the 'Costello syndrome' and 'familial erythrocytosis type 4', respectively, no case with PPGL has been reported in families with those syndromes. $^{2} 242646$ However, elevated urine catecholamine metabolites have been described in some patients with Costello syndrome $^{47}$ and EPAS1 mutations have been found as a mosaic in germline DNA extracted from leucocytes and buccal cells in two patients with polycythaemia and PPGLs. ${ }^{48} 49$ Although we have not ruled out the presence of these mutations in germline DNA, none of the cases with somatic mutations in EPAS1 or $H R A S$ showed any of the associated syndromic features. 


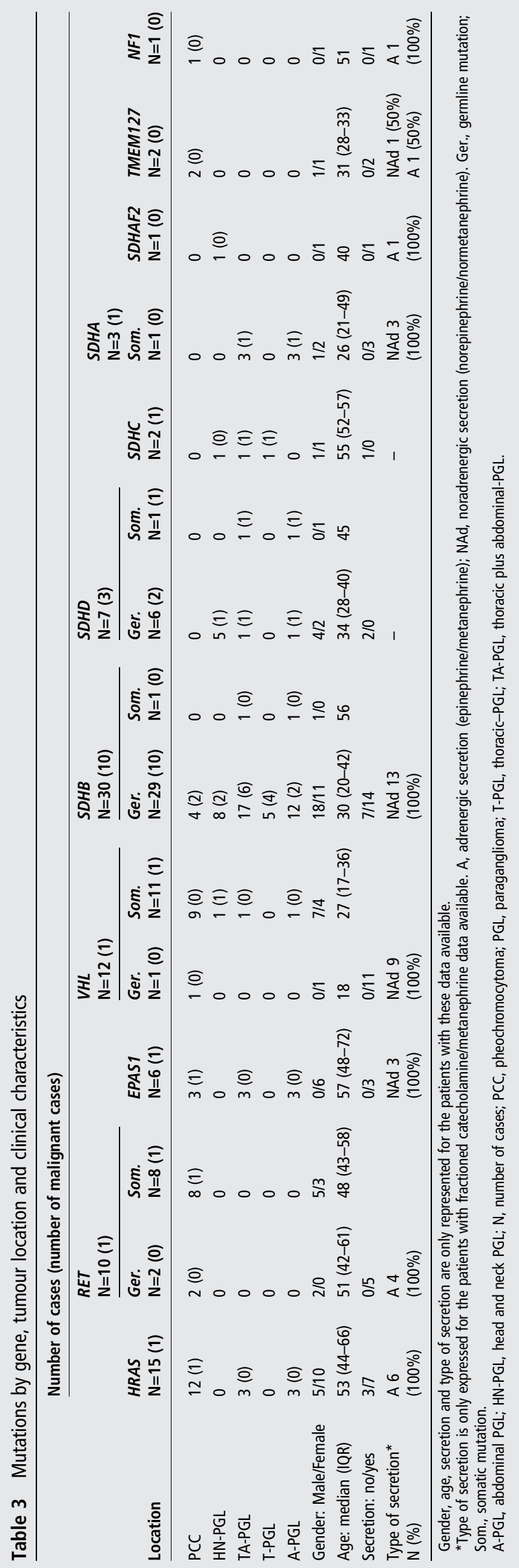

\section{Importance of differentiating specific location}

In addition to the predominant secretion, our study highlights the utility of differentiating tumour location to select not only the most appropriate DNA sample (germline or tumour), but also the genes to be studied. Our analysis enabled us to conclude that the study of germline DNA should be prioritised in HN-PGLs and T-PGLs, while the study of tumour DNA should be recommended in PCCs. Despite not finding statistically significant differences between the frequencies of somatic and germline mutations in A-PGLs, SDH genes were involved in $72 \%$ of mutated cases (being two somatic mutations). In addition, 20\% (3/15) of HRAS-mutated cases in this series were A-PGLs, compared with the $4.2 \% \quad(1 / 24)$ previously reported, ${ }^{11}{ }^{24}{ }^{26}$ highlighting the relevance of HRAS somatic testing in tumours located outside the adrenal glands. Finally, for A-PGLs, it seems appropriate to recommend a germline study (starting with the SDH genes) in cases with tumours negative for SDHB-IHC and somatic screening (excluding the SDH genes) in those with positive SDHB-IHC staining.

\section{Metastatic behaviour}

As expected, $S D H B$ was the main gene involved in metastatic S-PPGLs, even in cases with PCC. It was the most commonly mutated gene among T-PGLs (38.5\%). Somatic mutations in VHL, RET, EPAS1, HRAS and SDHD were detected in one case each. Thus, because knowing the driver mutation is especially important in the determination of the most appropriate therapeutic intervention, ${ }^{3}$ metastatic cases should not be excluded from comprehensive testing for somatic mutations.

\section{Age at onset}

Historically, paediatric age has been considered a predictor of the presence of germline mutations in PPGL-related genes. In fact, previous paediatric series have shown rates of germline mutation of around $80 \% .^{50}$ The results from the present study show that at least a quarter of S-PPGLs can be explained by somatic mutations, even in paediatric cases. So, it is also important to study somatic mutations in young patients.

Although there is no agreement on the upper age limit to apply for genetic testing, ${ }^{13-15} 182051 \quad 45$ years resulted in a better identification of mutation-positive cases in the study of Erlic et al, ${ }^{13}$ where various clinical parameters were assessed using multiple logistic regression. If germline screening had not been performed in index cases older than 45 years in our series, we would have missed $11.1 \%$ hereditary cases of HN-PGLs, $25 \%$ of T-PGLs, $8 \%$ of A-PGLs and $3.2 \%$ of PCCs. Conversely, younger patients tend to be excluded from somatic studies. Thus, if the somatic screening had not been performed in index cases younger than 45 years, we would have missed the genetic diagnosis of $42.9 \%$ A-PGLs, and even more importantly, $53.3 \%$ of PCCs. Therefore, we recommend that a germline and somatic genetic diagnosis be carried out for all S-PPGLs, regardless of the age of diagnosis.

Moreover, paediatric cases with somatic mutations should be assessed with caution, as it is especially important to rule out the presence of a mosaic. Mosaicism has been demonstrated to occur in EPAS1 patients. ${ }^{52}{ }^{53}$ NGS is a useful diagnostic tool to accurately quantify the level of mosaicism through the study of different embryological lineage cells. ${ }^{48}$ Thus, if a somatic mutation is found in a paediatric case, a search for the mutation in multiple tissues is encouraged to better evaluate the extension of the disease, as well as to improve the management and follow-up of the patient and their offspring. ${ }^{48}$ 


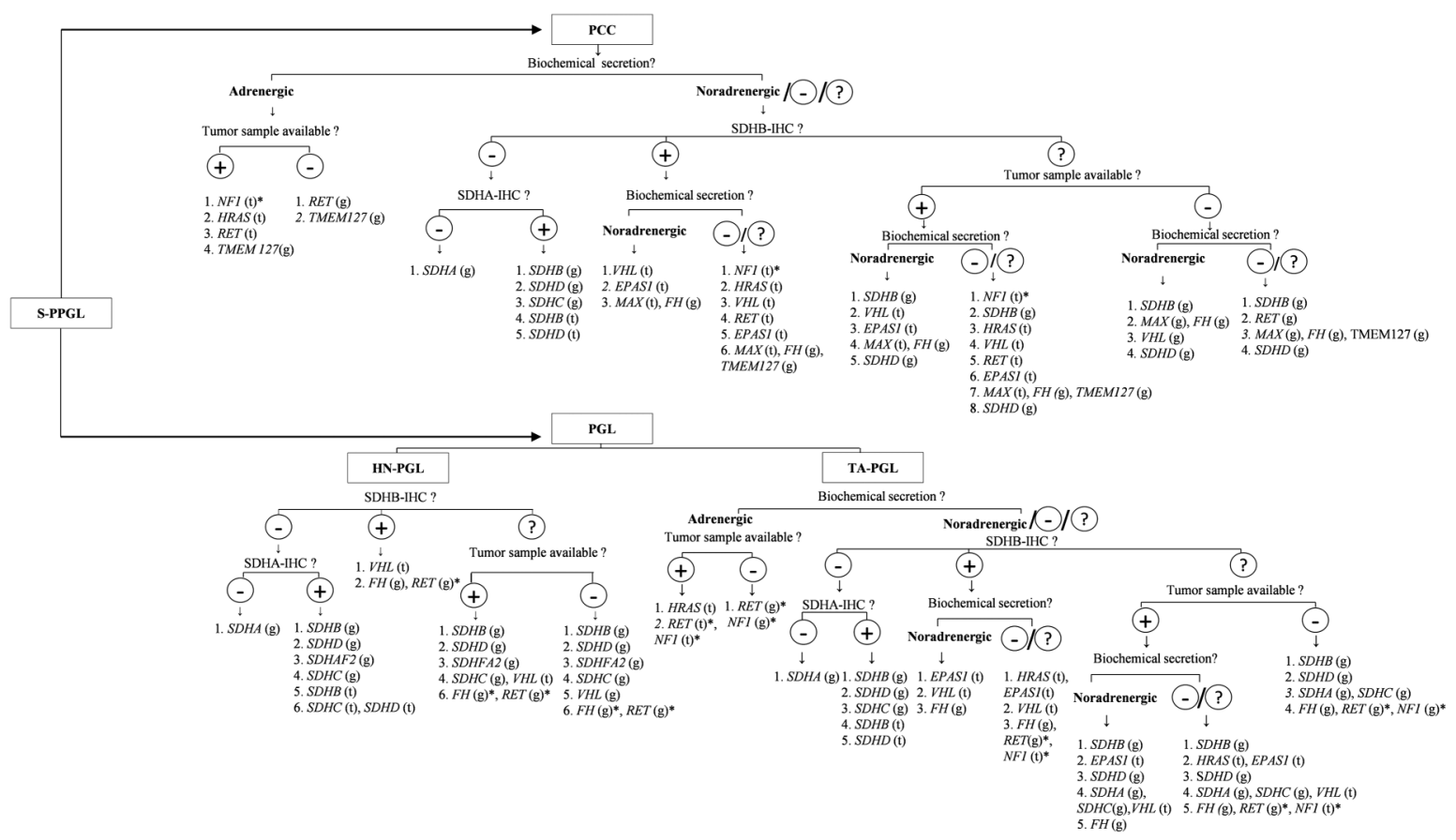

Figure 2 Proposed genetic testing algorithm for patients with sporadic-pheochromocytoma and paraganglioma (S-PPGL) based on SDHB-immunohistochemistry (IHC) in formalin-fixed paraffin-embedded tissue (if available) and biochemical phenotype. This algorithm has been elaborated considering previous reports' findings $5>11162327-3057$ and the current series. (g), germline DNA; HN-PGL, head and neck-paraganglioma; PCC, pheochromocytoma; PGL, paraganglioma; $(\mathrm{t})$, tumour DNA; TA-PGL, thoracic plus abdominal-paraganglioma. * Test if possible.

\section{Paraffin-embedded tumour samples}

The prevalence of mutations in the SDH genes in A-PGLs, metastatic cases, as well as paediatric S-PPGLs stresses the importance of using SDHB-IHC as a filter to optimise genetic screening, and therefore highlights the importance of having access to FFPE tumour material. ${ }^{3} 32$ Additionally, SDHA, MAX and S-(2-succinyl) cysteine IHC could also help to direct mutation testing of SDHA, MAX and FH, respectively. ${ }^{3} 25313241$ A good example of utility of performing IHC to guide the study was the case with a somatic mutation in SDHD. Somatic SDHs mutations are scarce and rarely analysed. When FFPE tumour material is unavailable, at a minimum $S D H B$ germline mutations should be tested for, given the higher associated risk of developing metastases ${ }^{54}$ and the presence of a founder effect, at least in the Spanish population. ${ }^{20}$

Even where NGS can be carried out, the large number of variants identified by this platform means that having access to FFPE tumour samples to perform IHC studies can help to select the genetic variants that should be validated by Sanger sequencing, and to determine the pathogenicity of variants of unknown significance found in these genes. ${ }^{11} 2728$

\section{Reasons to consider genetic screening in all cases of S-PPGLS}

Genetic screening is expensive and time-consuming, especially if NGS is not available, but there are important implications of having a genetic diagnosis in S-PPGLs. According to the American Society of Clinical Oncology (ASCO)'s general recommendations for genetic screening, all patients with a risk of at least $10 \%$ of carrying a genetic mutation should be offered genetic testing, especially when the results would aid in diagnosis or influence the management of the patient or family members at hereditary risk of cancer. ${ }^{16} 55$
The identification of a germline mutation in a patient with apparent S-PPGLs could lead to the early diagnosis of multiple tumours or additional syndromic neoplasias in the proband, as well as in relatives at risk.

On the other hand, the identification of a somatic mutation benefits: (1) family screening, as it frees relatives from the need for genetic screening and clinical follow-up (more caution has to be taken in the case of 'somatic mutations' in paediatric cases since the possibility of a germline mosaicism cannot be excluded); (2) diagnosis, making unjustified the exhaustive follow-up required for patients harbouring germline mutations associated with a high risk of developing different cancer types; (3) prognosis, as it is known that mutations in some genes have a well-known high risk of metastatic behaviour and (4) therapeutic opportunities, since the identification of the somatic mutation opens up the possibility of new therapeutic approaches if surgery is not curative. Mutations involving cluster 1 genes could be targeted using an antiangiogenic approach, mutations in cluster 2 genes could be treated by targeting the mTOR and the RAS-RAF pathway and, specifically, for FH-related and SDH-related malignant PPGLs, drugs targeting epigenetic pathways could be an option. Finally, the identification of a somatic mutation avoids additional germline genetic screening as new susceptibility genes are discovered, which is associated with considerable anxiety and psychological ill health, especially in relatives of paediatric and metastatic cases. ${ }^{2} 3275456$

In conclusion, the results of this study should bring to an end years of controversy and debate, as it brings new evidence that highlights the need to recommend genetic testing for all patients with an apparently S-PPGL, regardless of the age at first PPGL diagnosis.

Finally, based on the present and previous findings, $35711162327-3057$ we propose a genetic testing algorithm 
based on tumour location for sporadic single PPGL (figure 2), for laboratories where NGS is not available or not optimised. Where NGS can be used, the sample type that should be tested is tumour DNA for PCCs and germline DNA for HN-PGLs and T-PGLs. For A-PGLs, it seems crucial to have a FFPE tumour sample available in order to perform SDHB-IHC, the findings from which can be used to determine the ideal source of DNA sample to study.

\section{Author affiliations}

Hereditary Endocrine Cancer Group, Spanish National Cancer Research Centre, Madrid, Spain

${ }^{2}$ Centro de Investigación Biomédica en Red de Enfermedades Raras, Madrid, Spain

${ }^{3}$ Department of Endocrinology, Hospital General Universitario de Ciudad Real, Ciudad Real, Spain

${ }^{4}$ Department of Endocrinology, Hospital Universitario Severo Ochoa, Madrid, Spain

${ }^{5}$ Department of Endocrinology, Hospital Universitario Puerta de Hierro, Madrid, Spain

${ }^{6}$ Department of Endocrinology, Hospital Universitario La Paz, Madrid, Spain

${ }^{7}$ Department of Endocrinology, Hospital General Universitario Gregorio Marañón, Madrid, Spain

${ }^{8}$ Department of Endocrinology, Hospital Infanta Sofía, San Sebastián de los Reyes, Spain

${ }^{9}$ Department of Endocrinology, Hospital Universitario 12 de Octubre, Madrid, Spain

${ }^{10}$ Department of Endocrinology, Hospital Clínico San Carlos, Madrid, Spain

${ }^{11}$ Department of Endocrinology, Hospital El Bierzo, León, Spain

${ }^{12}$ Department of Endocrinology, Complejo Hospitalario Universitario de Albacete, Albacete, Spain

${ }^{13}$ Department of Endocrinology, Hospital Universitario de La Princesa, Instituto Princesa, Madrid, Spain

${ }^{14}$ Oncologic Pathology Group, Institut de Recerca Biomèdica de Lleida, Lleida, Spain

${ }^{15}$ Department of Endocrinology, Hospital General Universitario Reina Sofía, Murcia, Spain

${ }^{16}$ Department of Pediatrics and Clinical Genetics Unit, Clínica Universidad de Navarra, Navarra, Spain

${ }^{17}$ Department of Genetics, Hospital Universitario Virgen de las Nieves, Granada, Spain

${ }^{18}$ Department of Endocrinology, Hospital Universitario de Móstoles, Madrid, Spain

${ }^{19}$ Department of Pediatric Oncology and Hematology, Hospital Universitari Vall d'Hebron, Barcelona, Spain

${ }^{20}$ Department of Genetics, Hospital Universitario Donostia, Gipuzkoa, Spain

${ }^{21}$ Department of Endocrinology, Complejo Hospitalario de Navarra, Navarra, Spain

${ }^{22}$ Department of General Surgery and Digestive Tract, Complejo Asistencial de León, León, Spain

${ }^{23}$ Department of Endocrinology, Hospital Virgen de la Salud-Complejo Hospitalario de Toledo, Toledo, Spain

${ }^{24}$ Department of Otorhinolaryngology, Hospital General Universitario Gregorio Marañón, Madrid, Spain

${ }^{25}$ Genetic Counselling Cancer Unit, Hospital Universitari i Politecnic La Fe, Valencia, Spain

${ }^{26}$ Department of Endocrinology, Hospital General Universitario de Alicante, Alicante, Spain

${ }^{27}$ Department of Endocrinology, Hospital Universitario de Fuenlabrada, Madrid,

Spain

${ }^{28}$ Erasmus Universitair Medisch Centrum Rotterdam, Rotterdam, The Netherlands

Acknowledgements Tumour samples were obtained with the support of the Spanish National Tumor Bank Network, the Red Nacional de Biobancos (RD09/ 0076/00047). We thank all the medical doctors and tumour biobanks of the public and private Spanish hospitals involved in the management of patients affected by PPGLs. We would like to specially thank the Biobank of Sistema Sanitario Público de Andalucía, Complejo Hospitalario Universitario de Albacete and the Hospital de León.

Contributors MC-F, AC and MR contributed to the acquisition, analysis and interpretation of data and drafting of the manuscript. LI-P, VM, CM-C, RL and CR-A contributed to analysis, data interpretation and revising the manuscript for intellectual content. EK contributed to the somatic study of NF1 and SDHD, and SDHA-IHC; IC-M, MA-R, LS-B, MAS-C, VA, JA, CA-E, VMA-M, SA-M, MC-G, JAD, AD-H, CL-O, MM, XM-G, AM-A, AP-G, SP, GR-E, CS-A, RS-V, AST, OSG, JS-M, BS-Y, AS-H, MSS-C, MRV-V contributed to data acquisition and revising the manuscript for intellectual content. All coauthors have approved the final version of the manuscript. No other persons contributed in a way that they are entitled to be coauthors.

Funding This work was supported in part by the Fondo de Investigaciones Sanitarias (projects PI14/00240), FEDER 2014-2020 and the GETNE (Grupo
Español de Tumores Neuroendocrinos). Maria Currás is a predoctoral fellow supported by the Severo Ochoa Excellence Programme (project SEV-2011-0191). Lucía Inglada-Pérez is supported by CIBERER. Veronika Mancikova and Maria Apellániz are predoctoral fellows of "la Caixa"/CNIO international PhD programme. Iñaki Comino is a predoctoral fellow supported by the Fondo de Investigaciones Sanitarias (project PI12/00236). Lara Sánchez is supported by the Spanish Ministry of Economy and Competiveness (grant number SAF2012-35779).

Competing interests None declared.

Patient consent Obtained.

Ethics approval This study only included patients who had signed the informed consent for genetic diagnosis.

Provenance and peer review Not commissioned; externally peer reviewed.

Data sharing statement Except for the raw data, no additional data are available. Raw data may be made available if it does not infringe patients' rights.

\section{REFERENCES}

1 Lenders JW, Duh OY, Eisenhofer G, Gimenez-Roqueplo AP, Grebe SK, Murad MH Naruse M, Pacak K, Young WF Jr. Pheochromocytoma and paraganglioma: an endocrine society clinical practice guideline. J Clin Endocrinol Metab 2014;99:1915-42.

2 Dahia PL. Pheochromocytoma and paraganglioma pathogenesis: learning from genetic heterogeneity. Nat Rev Cancer 2014;14:108-19.

3 Favier J, Amar L, Gimenez-Roqueplo AP. Paraganglioma and phaeochromocytoma: from genetics to personalized medicine. Nat Rev Endocrinol 2015;11:101-11.

4 Cawthon RM, Weiss R, Xu GF, Viskochil D, Culver M, Stevens J, Robertson M, Dunn D, Gesteland R, O'Connell P. A major segment of the neurofibromatosis type 1 gene: cDNA sequence, genomic structure, and point mutations. Cell 1990;62:193-201.

5 Martucci VL, Pacak K. Pheochromocytoma and paraganglioma: diagnosis, genetics, management, and treatment. Curr Prob/ Cancer 2014;38:7-41.

6 van Nederveen FH, Korpershoek E, Lenders JW, de Krijger RR, Dinjens WN. Somatic SDHB mutation in an extraadrenal pheochromocytoma. $N$ Engl J Med 2007:357:306-8.

7 Welander J, Soderkvist P, Gimm 0. Genetics and clinical characteristics of hereditary pheochromocytomas and paragangliomas. Endocr Relat Cancer 2011;18:R253-76.

8 Yang C, Zhuang Z, Fliedner SM, Shankavaram U, Sun MG, Bullova P, Zhu R Elkahloun AG, Kourlas PJ, Merino M, Kebebew E, Pacak K. Germ-line PHD1 and PHD2 mutations detected in patients with pheochromocytoma/ paraganglioma-polycythemia. J Mol Med (Berl) 2015;93:93-104.

9 Cascon A, Comino-Mendez I, Curras-Freixes M, de Cubas AA, Contreras L, Richter S, Peitzsch M, Mancikova V, Inglada-Perez L, Perez-Barrios A, Calatayud M, Azriel S, Villar-Vicente R, Aller J, Setien F, Moran S, Garcia JF, Rio-Machin A, Leton R, Gomez-Grana A, Apellaniz-Ruiz M, Roncador G, Esteller M, Rodriguez-Antona C, Satrustegui J, Eisenhofer G, Urioste M, Robledo M. Whole-exome sequencing identifies MDH2 as a new familial paraganglioma gene. J Nat/ Cancer Inst 2015; 107. pii: djv053.

10 Fishbein L, Khare S, Wubbenhorst B, DeSloover D, D'Andrea K, Merrill S, Cho NW, Greenberg RA, Else T, Montone K, LiVolsi V, Fraker D, Daber R, Cohen DL, Nathanson KL. Whole-exome sequencing identifies somatic ATRX mutations in pheochromocytomas and paragangliomas. Nat Commun 2015;6:6140.

11 Luchetti A, Walsh D, Rodger F, Clark G, Martin T, Irving R, Sanna M, Yao M, Robledo M, Neumann HP, Woodward ER, Latif F, Abbs S, Martin H, Maher ER Profiling of somatic mutations in phaeochromocytoma and paraganglioma by targeted next generation sequencing analysis. Int J Endocrinol 2015;2015:138573.

12 Bausch B, Koschker AC, Fassnacht M, Stoevesandt J, Hoffmann MM, Eng C, Allolio $B$, Neumann HP. Comprehensive mutation scanning of NF1 in apparently sporadic cases of pheochromocytoma. J Clin Endocrinol Metab 2006:91:3478-81.

13 Erlic Z, Rybicki L, Peczkowska M, Golcher H, Kann PH, Brauckhoff M, Mussig K, Muresan M, Schaffler A, Reisch N, Schott M, Fassnacht M, Opocher G, Klose S, Fottner C, Forrer F, Plockinger U, Petersenn S, Zabolotny D, Kollukch O, Yaremchuk S, Januszewicz A, Walz MK, Eng C, Neumann HP. Clinical predictors and algorithm for the genetic diagnosis of pheochromocytoma patients. Clin Cancer Res 2009;15:6378-85.

14 Mannelli M, Castellano M, Schiavi F, Filetti S, Giacche M, Mori L, Pignataro V, Bernini G, Giache V, Bacca A, Biondi B, Corona G, Di Trapani G, Grossrubatscher E, Reimondo G, Arnaldi G, Giacchetti G, Veglio F, Loli P, Colao A, Ambrosio MR, Terzolo M, Letizia C, Ercolino T, Opocher G. Clinically guided genetic screening in a large cohort of italian patients with pheochromocytomas and/or functional or nonfunctional paragangliomas. J Clin Endocrinol Metab 2009;94:1541-7.

15 Cascon A, Lopez-Jimenez E, Landa I, Leskela S, Leandro-Garcia LJ, Maliszewska A, Leton R, de la Vega L, Garcia-Barcina MJ, Sanabria C, Alvarez-Escola C, Rodriguez-Antona C, Robledo M. Rationalization of genetic testing in patients with apparently sporadic pheochromocytoma/paraganglioma. Horm Metab Res 2009;:11:672-5. 
16 Martins R, Bugalho MJ. Paragangliomas/pheochromocytomas: clinically oriented genetic testing. Int J Endocrinol 2014;2014:794187.

17 Brito JP, Asi N, Bancos I, Gionfriddo MR, Zeballos-Palacios CL, Leppin AL, Undavalli C, Wang Z, Domecq JP, Prustsky G, Elraiyah TA, Prokop LJ, Montori VM, Murad $\mathrm{MH}$. Testing for germline mutations in sporadic pheochromocytoma/paraganglioma: a systematic review. Clin Endocrinol (Oxf) 2015;82:338-45.

18 Amar L, Bertherat J, Baudin E, Aizenberg C, Bressac-de Paillerets B, Chabre O, Chamontin B, Delemer B, Giraud S, Murat A, Niccoli-Sire P, Richard S, Rohmer V, Sadoul JL, Strompf L, Schlumberger M, Bertagna X, Plouin PF, Jeunemaitre X, Gimenez-Roqueplo AP. Genetic testing in pheochromocytoma or functional paraganglioma. J Clin Oncol 2005;23:8812-18.

19 Neumann HP, Bausch B, McWhinney SR, Bender BU, Gimm O, Franke G, Schipper J, Klisch J, Altehoefer C, Zerres K, Januszewicz A, Eng C, Smith WM, Munk R, Manz T, Glaesker S, Apel TW, Treier M, Reineke M, Walz MK, Hoang-Vu C, Brauckhoff M, Klein-Franke A, Klose P, Schmidt H, Maier-Woelfle M, Peczkowska $\mathrm{M}$, Szmigielski C. Germ-line mutations in nonsyndromic pheochromocytoma. N Engl J Med 2002;346:1459-66.

20 Cascon A, Pita G, Burnichon N, Landa I, Lopez-Jimenez E, Montero-Conde C, Leskela S, Leandro-Garcia LJ, Leton R, Rodriguez-Antona C, Diaz JA, Lopez-Vidriero E, Gonzalez-Neira A, Velasco A, Matias-Guiu X, Gimenez-Roqueplo AP, Robledo M. Genetics of pheochromocytoma and paraganglioma in Spanish patients. J Clin Endocrinol Metab 2009;94:1701-5.

21 Burnichon N, Vescovo L, Amar L, Libe R, de Reynies A, Venisse A, Jouanno E, Laurendeau I, Parfait B, Bertherat J, Plouin PF, Jeunemaitre X, Favier J, Gimenez-Roqueplo AP. Integrative genomic analysis reveals somatic mutations in pheochromocytoma and paraganglioma. Hum Mol Genet 2011;20:3974-85.

22 Burnichon N, Buffet A, Parfait B, Letouze E, Laurendeau I, Loriot C, Pasmant E, Abermil N, Valeyrie-Allanore L, Bertherat J, Amar L, Vidaud D, Favier J, Gimenez-Roqueplo AP. Somatic NF1 inactivation is a frequent event in sporadic pheochromocytoma. Hum Mol Genet 2012;21:5397-405.

23 Welander J, Larsson C, Backdahl M, Hareni N, Sivler T, Brauckhoff M, Soderkvist P, Gimm 0. Integrative genomics reveals frequent somatic NF1 mutations in sporadic pheochromocytomas. Hum Mol Genet 2012;21:5406-16.

24 Crona J, Delgado Verdugo A, Maharjan R, Stalberg P, Granberg D, Hellman P, Bjorklund P. Somatic mutations in H-RAS in sporadic pheochromocytoma and paraganglioma identified by exome sequencing. J Clin Endocrinol Metab 2013;98: E1266-71.

25 Burnichon N, Cascon A, Schiavi F, Morales NP, Comino-Mendez I, Abermil N, Inglada-Perez L, de Cubas AA, Amar L, Barontini M, de Quiros SB, Bertherat J, Bignon YJ, Blok MJ, Bobisse S, Borrego S, Castellano M, Chanson P, Chiara MD, Corssmit EP, Giacche M, de Krijger RR, Ercolino T, Girerd X, Gomez-Garcia EB, Gomez-Grana A, Guilhem I, Hes FJ, Honrado E, Korpershoek E, Lenders JW, Leton $R$, Mensenkamp AR, Merlo A, Mori L, Murat A, Pierre P, Plouin PF, Prodanov T, Quesada-Charneco M, Qin N, Rapizzi E, Raymond V, Reisch N, Roncador G, Ruiz-Ferrer M, Schillo F, Stegmann AP, Suarez C, Taschin E, Timmers HJ, Tops CM, Urioste M, Beuschlein F, Pacak K, Mannelli M, Dahia PL, Opocher G, Eisenhofer G, Gimenez-Roqueplo AP, Robledo M. MAX mutations cause hereditary and sporadic pheochromocytoma and paraganglioma. Clin Cancer Res 2012;18:2828-37.

26 Oudijk L, de Krijger RR, Rapa I, Beuschlein F, de Cubas AA, Dei Tos AP, Dinjens WN, Korpershoek E, Mancikova V, Mannelli M, Papotti M, Vatrano S, Robledo M, Volante M. H-RAS mutations are restricted to sporadic pheochromocytomas lacking specific clinical or pathological features: data from a multi-institutional series. J Clin Endocrinol Metab 2014:99:E1376-80.

27 Casey R, Garrahy A, Tuthill A, O'Halloran D, Joyce C, Casey MB, O'Shea P, Bell M. Universal genetic screening uncovers a novel presentation of an SDHAF2 mutation. J Clin Endocrinol Metab 2014;99:E1392-6.

28 Rattenberry E, Vialard L, Yeung A, Bair H, McKay K, Jafri M, Canham N, Cole TR, Denes J, Hodgson SV, Irving R, Izatt L, Korbonits M, Kumar AV, Lalloo F, Morrison PJ, Woodward ER, Macdonald F, Wallis Y, Maher ER. A comprehensive next generation sequencing-based genetic testing strategy to improve diagnosis of inherited pheochromocytoma and paraganglioma. J Clin Endocrinol Metab 2013;98: E1248-56.

29 Welander J, Andreasson A, Juhlin CC, Wiseman RW, Backdahl M, Hoog A, Larsson C, Gimm O, Soderkvist P. Rare germline mutations identified by targeted next-generation sequencing of susceptibility genes in pheochromocytoma and paraganglioma. J Clin Endocrinol Metab 2014;99:E1352-60.

30 Crona J, Nordling M, Maharjan R, Granberg D, Stalberg P, Hellman P, Bjorklund P. Integrative genetic characterization and phenotype correlations in pheochromocytoma and paraganglioma tumours. PLoS One 2014;9:e86756.

31 Korpershoek E, Favier J, Gaal J, Burnichon N, van Gessel B, Oudijk L, Badoual C, Gadessaud N, Venisse A, Bayley JP, van Dooren MF, de Herder WW, Tissier F, Plouin PF, van Nederveen FH, Dinjens WN, Gimenez-Roqueplo AP, de Krijger RR. SDHA immunohistochemistry detects germline SDHA gene mutations in apparently sporadic paragangliomas and pheochromocytomas. J Clin Endocrinol Metab 2011:96:E1472-6.

32 van Nederveen FH, Gaal J, Favier J, Korpershoek E, Oldenburg RA, de Bruyn EM, Sleddens HF, Derkx P, Riviere J, Dannenberg H, Petri BJ, Komminoth P, Pacak K, Hop WC, Pollard PJ, Mannelli M, Bayley JP, Perren A, Niemann S, Verhofstad AA, de Bruine AP, Maher ER, Tissier F, Meatchi T, Badoual C, Bertherat J, Amar L, Alataki D, Van Marck E, Ferrau F, Francois J, de Herder WW, Peeters MP, van Linge A, Lenders JW, Gimenez-Roqueplo AP, de Krijger RR, Dinjens WN. An immunohistochemical procedure to detect patients with paraganglioma and phaeochromocytoma with germline SDHB, SDHC, or SDHD gene mutations: a retrospective and prospective analysis. Lancet Oncol 2009;10:764-71.

33 Sambrook J, Russell DW. Molecular cloning: a laboratory manual. 3rd edn. Cold Spring Harbor, NY: Cold Spring Harbor Laboratory Press, 2001.

34 Yao L, Schiavi F, Cascon A, Qin Y, Inglada-Perez L, King EE, Toledo RA, Ercolino T, Rapizzi E, Ricketts CJ, Mori L, Giacche M, Mendola A, Taschin E, Boaretto F, Loli P, lacobone M, Rossi GP, Biondi B, Lima-Junior JV, Kater CE, Bex M, Vikkula M, Grossman AB, Gruber SB, Barontini M, Persu A, Castellano M, Toledo SP, Maher ER, Mannelli M, Opocher G, Robledo M, Dahia PL. Spectrum and prevalence of FP/TMEM127 gene mutations in pheochromocytomas and paragangliomas. JAMA 2010;304:2611-19.

35 Comino-Mendez I, Gracia-Aznarez FJ, Schiavi F, Landa I, Leandro-Garcia LJ, Leton R, Honrado E, Ramos-Medina R, Caronia D, Pita G, Gomez-Grana A, de Cubas AA, Inglada-Perez L, Maliszewska A, Taschin E, Bobisse S, Pica G, Loli P, Hernandez-Lavado R, Diaz JA, Gomez-Morales M, Gonzalez-Neira A, Roncador G, Rodriguez-Antona C, Benitez J, Mannelli M, Opocher G, Robledo M, Cascon A. Exome sequencing identifies MAX mutations as a cause of hereditary pheochromocytoma. Nat Genet 2011;43:663-7.

36 Cascon A, Montero-Conde C, Ruiz-Llorente S, Mercadillo F, Leton R, Rodriguez-Antona C, Martinez-Delgado B, Delgado M, Diez A, Rovira A, Diaz JA, Robledo M. Gross SDHB deletions in patients with paraganglioma detected by multiplex PCR: a possible hot spot?. Genes Chromosomes Cancer 2006;45:213-19.

37 Pasmant E, Sabbagh A, Masliah-Planchon J, Ortonne N, Laurendeau I, Melin L, Ferkal S, Hernandez L, Leroy K, Valeyrie-Allanore L, Parfait B, Vidaud D, Bieche I, Lantieri L, Wolkenstein P, Vidaud M. Role of noncoding RNA ANRIL in genesis of plexiform neurofibromas in neurofibromatosis type 1. J Natl Cancer Inst 2011;103:1713-22.

38 Capatina C, Ntali G, Karavitaki N, Grossman AB. The management of head-and-neck paragangliomas. Endocr Relat Cancer 2013;20:R291-305.

39 Abermil N, Guillaud-Bataille M, Burnichon N, Venisse A, Manivet P, Guignat L, Drui D, Chupin M, Josseaume C, Affres H, Plouin PF, Bertherat J, Jeunemaitre $X$, Gimenez-Roqueplo AP. TMEM127 screening in a large cohort of patients with pheochromocytoma and/or paraganglioma. J Clin Endocrinol Metab 2012;97:E805-9.

40 Bayley JP, Kunst HP, Cascon A, Sampietro ML, Gaal J, Korpershoek E, Hinojar-Gutierrez A, Timmers HJ, Hoefsloot LH, Hermsen MA, Suarez C, Hussain $A K$, Vriends AH, Hes FJ, Jansen JC, Tops CM, Corssmit EP, de Knijff P, Lenders JW, Cremers CW, Devilee P, Dinjens WN, de Krijger RR, Robledo M. SDHAF2 mutations in familial and sporadic paraganglioma and phaeochromocytoma. Lancet Oncol 2010;11:366-72

41 Castro-Vega L, Buffet A, De Cubas AA, Cascon A, Menara M, Khalifa E, Amar L, Azriel S, Bourdeau I, Chabre O, Curras-Freixes M, Franco-Vidal V, Guillaud-Bataille M, Simian C, Morin A, Leton R, Gomez-Grana A, Pollard PJ, Rustin P, Robledo M, Favier J, Gimenez-Roqueplo AP. Germline mutations in FH confer predisposition to malignant pheochromocytomas and paragangliomas. Hum Mol Genet 2014:23:2440-6

42 Gimm O, Armanios M, Dziema H, Neumann HP, Eng C. Somatic and occult germ-line mutations in SDHD, a mitochondrial complex II gene, in nonfamilial pheochromocytoma. Cancer Res 2000;60:6822-5.

43 Jimenez C, Cote G, Arnold A, Gagel RF. Review: Should patients with apparently sporadic pheochromocytomas or paragangliomas be screened for hereditary syndromes? J Clin Endocrinol Metab 2006;91:2851-8.

44 Comino-Mendez I, de Cubas AA, Bernal C, Alvarez-Escola C, Sanchez-Malo C, Ramirez-Tortosa CL, Pedrinaci S, Rapizzi E, Ercolino T, Bernini G, Bacca A, Leton R, Pita G, Alonso MR, Leandro-Garcia LJ, Gomez-Grana A, Inglada-Perez L, Mancikova V, Rodriguez-Antona C, Mannelli M, Robledo M, Cascon A. Tumoral EPAS1 (HIF2A) mutations explain sporadic pheochromocytoma and paraganglioma in the absence of erythrocytosis. Hum Mol Genet 2013;22:2169-76.

45 Sue M, Martucci V, Frey F, Lenders J, Timmers HJ, Peczkowska M, Prejbisz A, Swantje B, Bornstein SR, Arlt W, Fassnacht M, Beuschlein F, Robledo M, Pacak K, Eisenhofer $\mathrm{G}$. Lack of utility of SDHB mutation testing in adrenergic metastatic phaeochromocytoma. Eur J Endocrinol 2015;172:89-95.

46 Dahia PL. The genetic landscape of pheochromocytomas and paragangliomas: somatic mutations take center stage. J Clin Endocrinol Metab 2013;98:2679-81.

47 Gripp KW, Kawame H, Viskochil DH, Nicholson L. Elevated catecholamine metabolites in patients with Costello syndrome. Am J Med Genet A 2004;128A:48-51.

48 Buffet A, Smati S, Mansuy L, Menara M, Lebras M, Heymann MF, Simian C, Favier J, Murat A, Cariou B, Gimenez-Roqueplo AP. Mosaicism in HIF2A-related polycythemia-paraganglioma syndrome. I Clin Endocrinol Metab 2014:99:E369-73.

49 Lorenzo FR, Yang C, Ng Tang Fui M, Vankayalapati H, Zhuang Z, Huynh T, Grossmann M, Pacak K, Prchal JT. A novel EPAS1/HIF2A germline mutation in a congenital polycythemia with paraganglioma. J Mol Med (Berl) 2013;91:507-12.

50 Bausch B, Wellner U, Bausch D, Schiavi F, Barontini M, Sanso G, Walz MK, Peczkowska M, Weryha G, Dall'igna P, Cecchetto G, Bisogno G, Moeller LC, 
Bockenhauer D, Patocs A, Racz K, Zabolotnyi D, Yaremchuk S, Dzivite-Krisane I, Castinetti F, Taieb D, Malinoc A, von Dobschuetz E, Roessler J, Schmid KW, Opocher G, Eng C, Neumann HP. Long-term prognosis of patients with pediatric pheochromocytoma. Endocr Relat Cancer 2014;21:17-25.

51 Cascon A, Inglada-Perez L, Comino-Mendez I, de Cubas AA, Leton R, Mora J, Marazuela M, Galofre JC, Quesada-Charneco M, Robledo M. Genetics of pheochromocytoma and paraganglioma in Spanish pediatric patients. Endocr Relat Cancer 2013:20:L1-6.

52 Zhuang Z, Yang C, Lorenzo F, Merino M, Fojo T, Kebebew E, Popovic V, Stratakis CA, Prchal JT, Pacak K. Somatic HIF2A gain-of-function mutations in paraganglioma with polycythemia. N Engl J Med 2012;367:922-30.

53 Favier J, Buffet A, Gimenez-Roqueplo AP. HIF2A mutations in paraganglioma with polycythemia. N Engl J Med 2012;367:2161; author reply-2.
54 Gimenez-Roqueplo AP, Favier J, Rustin P, Rieubland C, Crespin M, Nau V, Khau Van Kien P, Corvol P, Plouin PF, Jeunemaitre X. Mutations in the SDHB gene are associated with extra-adrenal and/or malignant phaeochromocytomas. Cancer Res 2003;63:5615-21.

55 [No authors listed]. Statement of the American Society of Clinical Oncology: genetic testing for cancer susceptibility, Adopted on February 20, 1996. J Clin Oncol 1996;14:1730-6; discussion 7-40.

56 Fishbein L, Merrill S, Fraker DL, Cohen DL, Nathanson KL. Inherited mutations in pheochromocytoma and paraganglioma: why all patients should be offered genetic testing. Ann Surg Oncol 2013;20:1444-50.

57 lacobone M, Schiavi F, Bottussi M, Taschin E, Bobisse S, Fassina A, Opocher G, Favia G. Is genetic screening indicated in apparently sporadic pheochromocytomas and paragangliomas? Surgery 2011;150:1194-201. 